schools, and they have been actively engaged for some years in directing and assisting schools in their programmes and in liaison between them and the national organizations. The "AAPT-AIP Visiting Scientists Programs in Physics", now in their fifth year, provide the stimulus of visits to high schools and institutions of higher loarning and furnish valuable feed-back of information and recommendations concerning the chief local educational problems in physics. The Association's Committee on High School Awards recognizes ton high schools each year for excellence in the teaching of physics. The Institute's two booklets, Physics in Your High School and Why Should You Study Physics in High School? encourage enrolment in high school physics. A purchase guide has been prepared to assist schools in purchasing equipment under the National Defense Education Act, and a report, entitled Modern Physics Buildings, is intended to contribute towards the better design of physics building facilities in schools and colleges. In order that the activities of the Association and Institute should have the greatest impact, the organizations have established the "Regional Counsellor Program" in Physics. The regional counsellors comprise a group of some fifty physicists, chosen for their competence in physics, their interest in the improvement of physies teaching, and their ability to work effectively at local level in co-operation with school and college officials to improve physics teaching. A Regional Counsellor Office has been established at the American Institute of Physics within the Institute Office of Education and Manpower to co-ordinate and support the work of the counsellors. The counsellors are unpaid, but their expenses are reimbursed. The Regional Office ensures that the counsellors receive proper recognition both locally and nationally.

\section{Aspects of Automation}

Automation at Low Cost is the title of a series of six booklets being issued during the National Productivity Year by the Information Division of the Department of Scientific and Industrial Research. The first five, dealing with counting and weighing, temperature and humidity, control of liquids, simple automation of machine tools, and control of processes, have already been published; the sixth, Quality Control and Inspection, is in the press. In the earlier booklets in the series, a description is given of some of the methods that a manufacturer can use to indicate and control the conditions inside his equipment, for example, the temperature of a furnace, the level of a solution in a boiler, the humidity in a drying chamber, the rate of flow of liquid into a tank, or the weight of material being added to a mixing vessel. Booklet No. 5 deals with processes in which several properties must be measured and controlled, either sequentially from stage to stage or simultaneously (Control of Processes. Pp. 16. London: Information Division, Department of Scientific and Industrial Research, 1963). The intention is to show to the small manufacturer some of the ways in which he can obtain the benefits of automation in his batchproduction work, and that any capital expenditure on the introduction of automation would be recovered within a few years.

\section{Journal of Medical Entomology}

VoLUME 1, No. 1, of a new journal ontitled Journal of Medical Entomology made its appearance in April 1964 (Pp. 1-118. Honolulu, Hawaii: Entomology Department, B. P. Bishop Museum, 1964. Published quarterly. Subscription rates: Annual subscription 10 dollars per volume to institutions and dealers; 7 dollars to individuals). It is edited by J. L. Gressitt, supported by an editorial committee widely distributed round the world, and will publish papers dealing with all phrses of medical entomology and medical acarology, including systematics of insects and mites of importance in public health and in veterinary medicine. Articles exceeding one page in length are subject to a page charge of 12.50 dollars per printed page. Part 1, which runs to 117 pages, is well printed and produced (in double columns); the contributors are just about as widely distributed geographically as they could be; and the sixteen papers deal with taxonomy of mites, ticks and flies, the physiology of mosquitoes, the isolation of viruses from mosquitoes and ticks, the incidence of filariasis, and methods for mosquito surveys.

\section{Abstracts of Papers on Radio Engineering}

WIтH the viow of assisting in the general problem of the retrieval of scientific information, the British Institution of Radio Engineers has periodicelly published abstracts of papers which have appeared in its Journal. The first booklet of such abstracts was issued in 1955 (Nature, 176, 381; 1955) and the seventh edition has recently become available (Abstracts of Papers published in the Journal of the British Institution of Radio Engineers, 1952 to 1963 inclusive. Seventh edition. Pp. viii +108. London: Institution of Electronic and Radio Engineers, 1963. 10s. 6d.). This contains 885 abstracts of papers, articles and reports published in the Institution's Journal during the twelve-year period 1952-63 inclusive. The abstracts are arranged according to the Universal Decimal Classification System with alphabetical subject and author indexes. Abstracts and references to reports of the Institution on technical and educational matters are included under appropriate headings, as well as editorial articles discussing matters of general and scientific interest. The completion of these abstracts to 1963 is very appropriate, since the name of the publishing body has recently been changed to "The Institution of Electronic and Radio Engineers". This seventh edition of the Abstracts is bound in stiff-paper covers with a colour reproduction of the Institution's armorial bearings. In order to avoid confusion in the published literature, the Journal of the Institution will retain the title The Radio and Electronic Engineer, which was adopted in January 1963.

\section{Blakeney Point and Scolt Head Island}

Blakeney Point and Scolt Head Island, edited by J. A. Steers (The National Trust, London, 1964. 5s.), is a new guide which replaces one published in 1952. It includes $a$ description of the physical features of the area by Prof. Steors, who also edited the whole work. The botany and plant ecology were dealt with by the late Prof. F. W. Jane and Dr. D. J. B. White. There is an article on the bryophytes by Dr. E. Lodge, and on the insects, marine animals and mammals by Mr. E. A. Ellis. Prof. Jane also wrote the chapter on birds. The book should be invaluable to visitors to these two reserves; it is also a useful introduction to those interested in coastal ecology generally.

\section{Mechanisms of Carcinogenesis}

"IN spite of all our deficiencies in knowledge, I believe we are now in prospect of a comprehensive synthesis in understanding of the means of action of chemical, physical, viral and indeed purely genetic carcinogenic influences." These brave words were written recently by Prof. Alexander Haddow in his introduction to a recent issue of the British Medical Bulletin devoted to "Mechanisms of Carcinogenesis-Chemical, Physical and Viral" (20, No. 2; May, 1964. London: The British Council. 308.). Similar statements in the past have been premature, but the thirteen review articles that he is introducing give Prof. Haddow some justification for his optimism. Because carcinogenic substances are so diverse they must operate by biochemical routes of great variety, but all the 